\title{
MICROENCAPSULATION OF PULP OF MANGIFERA INDICA L. BY SPRAY DRYING AND ANTIOXIDANT ACTIVITY
}

\section{NERLIS PAOLA PAJARO CASTR0 ${ }^{*}$, CLEMENTE GRANADOS CONDE², MILADYS ESTHER TORRENEGRA ALARCÓN ${ }^{3}$, MARÍA DEL ROSARIO OSORIO FORTICH ${ }^{4}$, ENILSON JÓSE PAJARO CASTRO ${ }^{5}$, GLICERIO LEON MENDEZ ${ }^{6}$}

1Pharmaceutical Chemistry, Master of Pharmaceutical Sciences, Faculty of Sciences of the Health, University of Sucre, Medical and Pharmaceutical Sciences Group, ${ }^{2}$ Food Engineering, Master of Science and Food Technology, Faculty of Engineering, University of Cartagena, Research in Engineering, Innovation, Quality Food and Health Group (INCAS), ${ }^{3}$ Food Engineering, Master of Science and Food Technology, Center of Commerce and Services, Regional Bolivar, SENA, Research in Innovation and Biotechnology Group (GIBEI),

${ }_{4}^{4}$ Pharmaceutical Chemistry, Master of Biomedical Sciences, Faculty of Pharmaceutical Sciences, University of Cartagena, Research in

Technology Pharmaceutical, Cosmetic and of Food Group (GITFCA), ${ }^{5}$ Pharmaceutical Chemist, Faculty of Pharmaceutical Sciences,

University of Cartagena, Research in Technology Pharmaceutical, Cosmetic and of Food Group (GITFCA), ${ }^{6}$ Pharmaceutical Chemist, Magister in Pharmaceutical Sciences, Doctorate Student in Engineering, Faculty of Engineering. Foundation University Technological of Comfenalco, CIPTEC Research Group, Cra, 44 \# 30a-91, Cartagena, Bolívar, Colombia

Email: nerlis.pajaro@unisucre.edu.co

Received: 19 Jul 2017 Revised and Accepted: 02 Nov 2017

\section{ABSTRACT}

Objective: The objective of this study was to microencapsulate mango pulp (Mangifera indica L) flounder variety by the spray drying method and to evaluate its potential antioxidant activity.

Methods: The fruits were collected in the municipality of Turbana-Bolívar $\left(10^{\circ} 16^{\prime} 222^{\prime N} \mathrm{~N} 75^{\circ} 26^{\prime} 38^{\prime \prime} \mathrm{W}\right)$, Colombia. The pulps obtained from the healthy fruits were microencapsulated by the spray drying method. The obtained microcapsules were measured the particle size and the mineral content was determined. The antioxidant activity was determined by three methodologies: total phenols, DPPH•, and ABTS•+.

Results: The results obtained demonstrate that the microcapsules of the mango pulp (M. indica $\mathrm{L}$ ) have a mineral content in the following order of importance calcium>phosphorus>iron. The $\mathrm{IC}_{50}$ values for the $\mathrm{DPPH}^{\bullet}$ and $\mathrm{ABTS}^{*}$ assay were found to be $110.54 \pm 1.50 \mu \mathrm{g} / \mathrm{ml}$ and $65.33 \pm 1.00 \mu \mathrm{g} / \mathrm{ml}$ respectively. The total phenol content was $73.11 \pm 1.54 \mathrm{mg} \mathrm{AG} / 100 \mathrm{mg}$ of microcapsules, which may be related to the antioxidant activity.

Conclusion: The spray drying method was a suitable technique to microcapsulate the mango pulp (M. indica L), which was shown to possess antioxidant activity.

Keywords: Microencapsulation, Mangifera indica, Spray drying, Phenols

(C) 2017 The Authors. Published by Innovare Academic Sciences Pvt Ltd. This is an open-access article under the CC BY license (http://creativecommons.org/licenses/by/4.0/) DOI: http://dx.doi.org/10.22159/ijpps.2017v9i12.21437

\section{INTRODUCTION}

The tropical and subtropical countries are producers of a great variety of fruits that by their exotic characteristics of aromas, flavors, and nutritional contents are highly appreciated by the food industry, for the development of new techniques through which healthy products of excellent quality can be obtained with varied sensorial characteristics and easy use.

However, most of these fruits depend on the seasonality in the crops and high perishability, because their water contents are susceptible to the deterioration by enzymatic reactions, chemical, and microbial action [1-5]

Within this large group are found the chancleta mangoes, which national production reaches considerable volumes in periods of harvests, however, these are lost due to lack of technical assistance, due to transportation difficulties, and inadequate postharvest handling, generating large economic losses [6-7].

The drying of fruits is an increasingly used technique, which seeks to reduce the water content of products with humidity higher than $80 \%$, and thus achieve to prolong its shelf life. However, the dehydration techniques are very varied, and the quality of the dehydrated products depends fundamentally on the drying method applied. The powders obtained by spraying represent a viable alternative to obtain products of high commercial value due to the reduction of weight, ease of preservation, product quality in general, and by the diversity in its use [8-10]. The powder formulation facilitates the transport and preserves the product from the bacterial degradation by drastically reducing the water activity increasing the shelf life of the product. This process is presented as an option since it is desirable to retain most of the organoleptic and nutritional properties of the concentrate [11-13].

Currently, the powdered foods made from fruits and vegetables with good nutritional and hydration properties are of interest at industrial and commercial level. Accordingly, the objective of this research was to microencapsulate the mango pulp ( $M$. indica $\mathrm{L}$ ) chancleta variety by the spray drying method and to evaluate its potential antioxidant activity.

\section{MATERIALS AND METHODS}

\section{Chemicals and reagents}

Maltodextrin, ascorbic acid, $\mathrm{HCl}$, phosphowolfroic acid, phosphormolybdic acid, gallic acid, potassium persulfate, ethanol, were donated by the faculty of pharmaceutical sciences of the University of Cartagena.

Obtaining the pulp of the mango variety chancleta (M. indica L)

The chancleta variety mangoes were collected in the town of Turbana, located in the north of the department of Bolívar $\left(10^{\circ} 16\right.$ ' 22 "north latitude and $75^{\circ} 26^{\prime}$ '38" west longitude). 5.6 kilograms were purchased on a particular plot. The mangoes were selected taking into account that they were free of external damages and had commercial maturity; they were washed and blanched at $90^{\circ} \mathrm{C}$ for 5 min. The pulps were obtained through a mesh refiner of $1.5 \mathrm{~mm}$ of the aperture; they were packed in airtight bags and then cooled to a temperature of $4{ }^{\circ} \mathrm{C}[14]$. 


\section{Microencapsulation of the pulp}

Microencapsulation was performed by taking $300 \mathrm{~g}$ of maltodextrin which was added to $700 \mathrm{~g}$ of mango pulp with constant agitation. The preparation was homogenized with ultra-turrax ultraturrax IKA $\mathrm{T}-10$ basic at $14000 \mathrm{rpm}$ for $15 \mathrm{~min}$ and it was stored at $4{ }^{\circ} \mathrm{C}$ until being fed to the spray dryer [4].

\section{Spray drying of the pulp}

The mixture was fed to a buchi mini spray dryer model B-290 (BÜCHI Labortechnik, Germany). The inlet and outlet temperature were maintained between $170{ }^{\circ} \mathrm{C} \pm 5^{\circ} \mathrm{C}$ and $70{ }^{\circ} \mathrm{C} \pm 5{ }^{\circ} \mathrm{C}$, respectively. The obtained microcapsules were collected in a self-sealing polyethylene package and stored in a room with humidity and temperature controlled at $45 \%$ and $20 \pm 5{ }^{\circ} \mathrm{C}$ [15-19]. Subsequently, the samples were homogenized and tested for vitamin C content (ascorbic acid) by the iodometric titration method [2]. The contents of crude fiber, ash, fat, carbohydrates, and protein were determined according to the methodology described by Morillas and Delgado [2].

\section{Particle size}

For the measurement of the particles, a NIKON ECLIPSE E-100 microscope (40X lens) was used. Very small samples of microcapsules were placed on boxes for objects that later were placed in the grid of the equipment. The morphology, size, and edges of the particles were observed [15-18].

\section{Determination of minerals}

The dry and calcined samples (ash) were treated with $\mathrm{HCl}$ according to the method recommended by the AOAC. The phosphorus, calcium, and iron minerals were determined by the atomic absorption spectrophotometry [2].

\section{Measurement of antioxidant activity}

To determine the antioxidant activity of the microcapsules, three methodologies were used: total phenols, 1,1-diphenyl-2-picrylhydrazyl radical $\left(\mathrm{DPPH}^{\circ}\right)$, and 2,2'-azino-bis-(3-ethyl-benzothiazoline)-6 (ABTS ${ }^{+}$.

\section{Determination of the total phenols}

The total phenol content was determined by the Folin-Ciocalteu colourimetric method. A mixture of phosphowolfroic and phosphomolybdic acids in basic media was used as reagents, which were reduced by oxidizing the phenolic compounds, resulting in blue oxides of tungsten $\left(\mathrm{W}_{8} \mathrm{O}_{23}\right)$ and molybdenum $\left(\mathrm{Mo}_{8} \mathrm{O}_{23}\right)$. A standard curve was constructed using as standard gallic acid between 50-500 $\mu \mathrm{g} / \mathrm{ml}$.

The corresponding extract was diluted to a concentration at which the phenol content would be within the range of the standard curve. The results were expressed as $\mathrm{mg}$ gallic acid/250 ml sample. The absorbance readings were performed at $760 \mathrm{~nm}$ on a Thermo Scientific ${ }^{\mathrm{TM}}$ visible UV spectrophotometer GENESYS 10S [20-21].

\section{DPPH· radical method}

The scavenging activity of DPPH free radicals was determined using the method described by Silva et al. [22], with some modifications. $75 \mu \mathrm{l}$ of sample was added to $150 \mu \mathrm{L}$ of a methanolic solution of $\mathrm{DPPH}^{*}(100 \mu \mathrm{g} / \mathrm{ml})$ and incubated at room temperature for $30 \mathrm{~min}$, after which the disappearance of the DPPH radical was spectrophotometrically determined at $550 \mathrm{~nm}$ in the reader of microplates multiskan ex (Thermoscientific) [23-26]. Ascorbic acid was used as a positive control for the uptake of DPPH • radicals $(25$ $\mu \mathrm{g} / \mathrm{ml}$ ). The IC 50 was determined by evaluating several serial concentrations of the sample by linear regression analysis. The results were expressed as the mean \pm SD of the percentage of uptake of the DPPH• radical relative to the control group.

\section{ABTS'+radical method}

The free radical scavenging activity ABTS was determined using the method described by Re et al. [27], with some modifications. The ABTS radical was formed following the reaction of ABTS $3.5 \mathrm{mmol}$ with $1.25 \mathrm{mmol}$ of potassium persulfate (final concentration). The samples will be incubated between $2-8{ }^{\circ} \mathrm{C}$ and in the dark for 16 $24 \mathrm{~h}$. Once the ABTS radical was formed, it was diluted with ethanol until an absorbance of $0.7 \pm 0.05$ at $734 \mathrm{~nm}$ was obtained. At a volume of $190 \mu \mathrm{L}$ of the ABTS• radical dilution $10 \mu \mathrm{L}$ of the sample under study was added and incubated at room temperature for $5 \mathrm{~min}$, after passing this time the disappearance of the ABTS radical at $734 \mathrm{~nm}$ was spectrophotometrically determined in the multiskan exmicroplate reader (Thermo scientific) [28-30].

\section{Statistical analysis}

All the trials were performed by sextupled. The results were expressed as the mean $\pm \mathrm{SD}$ (standard deviation). The significant differences were determined by ANOVA analysis followed by Dunnett's or Tukey's test, or as appropriate.

\section{RESULTS}

The spray drying technique is based on the entrapment of the essential oil compounds on a solid matrix of starches to reduce their mobility. Fig. 1 shows the microencapsulation process of the mango pulp.

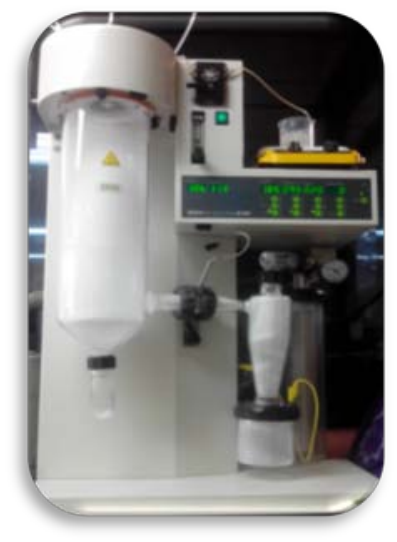

Fig. 1: Microencapsulation process by a spray dryer

Microcapsules obtained by spray-drying showed a spherical and smooth shape (fig. 2). The presence of rounded and smooth spheres, as shown, is desirable for the stability of the ingredients, and to control their release and to facilitate their solubility, properties that improve the effectiveness of the active ones when being incorporated in different complex matrices.

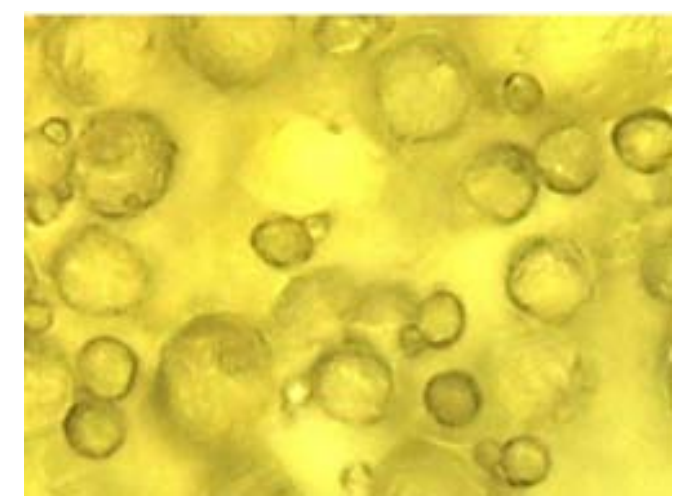

Fig. 2: Photograph of microcapsules of mango pulp, taken from NIKON ECLIPSE E-100 microscope (40X lens)

The chemical characterization of the microcapsules of the pulp $M$. indica $L$ chancleta variety cultivated in the north of the department of Bolívar-Colombia was carried out taking into account parameters such as ash content, moisture, protein, fats, fiber, carbohydrates, vitamin $\mathrm{C}$, calcium, phosphorus, iron, and particle size, the results 
are shown in table 1 . The increase in the inlet $\left(170^{\circ} \mathrm{C}\right)$ and outlet $\left(70^{\circ} \mathrm{C}\right)$ temperatures of the air decrease the moisture of the product by $1.86 \%$ which shows that as these temperatures increase, the rates of mass transfer and heat increase [4].

Table 1: Chemical characterization of the microcapsules of pulp of $M$. Indica L variety chancleta, cultivated in the north of the department of Bolivar - Colombia

\begin{tabular}{ll}
\hline Parameters evaluated & Chancleta (mean \pm SD)* \\
\cline { 2 - 2 } & Quantity 100 g \\
\hline Ash $(\mathrm{g})$ & $0.39 \pm 0.06$ \\
Humidity $(\mathrm{g})$ & $1.86 \pm 0.06$ \\
Protein $(\mathrm{g})$ & $0.55 \pm 0.05$ \\
Fat $(\mathrm{g})$ & $0.01 \pm 0.01$ \\
Crudefiber $(\mathrm{g})$ & $1.07 \pm 0.12$ \\
Carbohydrate $(\mathrm{g})$ & $97.21 \pm 0.05$ \\
Vitamin C (g) & $14.93 \pm 0.06$ \\
Calcium $(\mathrm{mg})$ & $11.63 \pm 0.55$ \\
Phosphorus $(\mathrm{mg})$ & $10.35 \pm 0.31$ \\
Iron $(\mathrm{mg})$ & $0.31 \pm 0.02$ \\
ParticleSize $(\mu \mathrm{m})$ & $5.92 \pm 2.18$ \\
\hline
\end{tabular}

$*_{\mathrm{n}}=3$

Although the fruits are not rich in minerals, they play a very important role in the balance of the human diet, especially because the composition of fruits differs from other foods of animal or vegetable origin $[2,3,14]$.

The order of importance of the minerals found in the mango pulp was as follows: calcium>phosphorus>iron.
The phenolic compounds quantified in fruit extracts are of great importance because they constitute a group of secondary metabolites that are considered natural antioxidants with multiple biological benefits for humans, such as the prevention of cardiovascular and degenerative diseases.

The antioxidant activity of the mango is shown in table 2 .

Table 2: Antioxidant activity of the microcapsules and pulp of $M$. indica $L$ variety chancleta, cultivated in the north of the department of bolívar-colombia

\begin{tabular}{|c|c|c|c|}
\hline Parameters evaluated & $\begin{array}{l}\text { Pulp of } M \text {. indica } \mathrm{L} \\
\text { mean } \pm \mathrm{SD}^{*}\end{array}$ & $\begin{array}{l}\text { Microcapsules of pulp of } M \text {. indica } \mathrm{L} \\
\text { mean } \pm \mathrm{SD}^{*}\end{array}$ & $\begin{array}{l}\text { Positive control (Ascorbic acid) } \\
\text { mean } \pm \text { SD }^{*}\end{array}$ \\
\hline $\mathrm{DPPH} \bullet \mathrm{IC}_{50}(\mu \mathrm{g} / \mathrm{ml})$ & $95.11 \pm 1.00$ & $110.54 \pm 1.50$ & $14.98 \pm 0.33$ \\
\hline ABTS $\bullet+\mathrm{IC}_{50}(\mu \mathrm{g} / \mathrm{ml})$ & $48.75 \pm 0.90$ & $65.33 \pm 1.00$ & $3.00 \pm 0.50$ \\
\hline $\begin{array}{l}\text { Total phenols (mg AG/100 mg } \\
\text { microcapsules) }\end{array}$ & $85.00 \pm 1.00$ & $73.11 \pm 1.54$ & --- \\
\hline
\end{tabular}

\footnotetext{
$*_{n}=3$
}

In fruits, it has been found that the main compounds present are mostly phenolic acids, flavonoids and tannins; however, phytochemicals such as vitamin C (ascorbic acid), folic acid (vitamin B), and $\beta$-carotene (provitamin A) are also been found, which makes it possible to establish that fruit consumption increases the intake of bioactive compounds with multiple properties for human health.

It is important to note that there are several internal and external factors that affect the quality and/or quantity of phenolic compounds in the plants, such as: the genetic diversity (variety and origin of the sample), stage of maturity, environmental variables (light intensity, climate, temperature, fertilizer use, wounds), method of extraction, processing, and storage [21].

The microcapsules studied showed a good antioxidant activity. The $\mathrm{IC}_{50}$ values for the DPPH and ABTS assay found were $110.54 \pm 1.50$ $\mu \mathrm{g} / \mathrm{ml}$ and $65.33 \pm 1.00 \mu \mathrm{g} / \mathrm{ml}$ respectively. The antioxidant activity of these horticultural products can be related to the total phenols contents.

\section{DISCUSSION}

The mango pulp could be microencapsulated by the spray drying method, retaining its antioxidant properties and with an efficiency of $98 \% \pm 0.50 \%$. The particle size of the microcapsules was $5.92 \pm 2.18$ $\mu \mathrm{m}$, this being a suitable size to maintain stability and preserve the effectiveness of the product.

At present, several studies have focused on the drying of different types of fruits, in fact, during the process of obtaining guava powder by spray drying, Patil et al. [31] found that the increase in the inlet temperature and the maltodextrin concentration significantly decreased the moisture of the product obtained.

Caliskan and Nur [32] reported consistent results, where the increase in inlet and outlet temperatures decreased the moisture content of the product due to high operating temperatures leading to high heat transfer values.

Krishnaiah et al. [33] also found that for the powder of the extract of Morinda citrifolia obtained by spray drying, the humidity decreased with the increase in the inlet and outlet temperatures of the process, attributing this also to higher heat transfer rates, providing a greater driving force for moisture evaporation.

Due to in the spray drying the heat is directly involved, the thermal degradation is the most important deleterious phenomenon, the loss or thermal degradation of antioxidant metabolites (ascorbic acid), which are thermolabile compounds [4, 34-35]. In the thermal degradation, the chemical compounds undergo significant changes in their structure (loss of one or more atoms of the fundamental structure) due to the action of high temperatures, resulting in a loss of the properties of compound [4]. However, ascorbic acid content ranging from 9.79 to $186 \mathrm{mg} / 100 \mathrm{~g}$ of mango pulp [7]. Moreira et al. (2001) [36] reported the content of ascorbic acid of $37 \mathrm{mg} / 100 \mathrm{~g}$, values that are below the value reported in the present investigation. In this work it was observed that the microencapsulation process does not affect the antioxidant activity of the pulp of $M$. indica L, in addition, our results are higher than those obtained for the positive control (table 2). 
The availability of maltodextrin in the product increases the structure of the granule giving rise to larger particles. Pang et al. [37] similarly discloses the increase in the size of the particles of the orthosiphon extract during spray drying as the concentration of maltodextrin increases.

On the other hand, Tonon et al. [38] reported that the increase in maltodextrin concentration from $10 \%$ to $30 \%$ produced larger particles in the acai powder $(13,27 \mu \mathrm{m}$ to $21,35 \mu \mathrm{m})$ obtained by spray drying, which attributed to the exponential increase in the viscosity of the feed liquid, which in turn causes larger droplets during the drying process.

The phenol content is related to the antioxidant activity; in fact, other studies indicate that the phenols act by the elimination of free radicals [39]. The content of phenol in the microcapsules was $73.11 \pm 1.54 \mathrm{mg} \mathrm{AG} / 100 \mathrm{mg}$ microcapsules, this value is higher than reported in other studies for freeze-dried powder from Syzygium cumini, which was $13.99 \mathrm{mg}$ GA equivalents/10 $\mathrm{mg}$ and is reported with a high antioxidant power [40].

\section{CONCLUSION}

Spray drying was a suitable technique for the dehydration of the mango pulp because it increased the chemical stability, improved the manipulation and conserved to a great extent the nutraceutical metabolites of the fruit. The results revealed that the percentage of preservation of ascorbic acid (vitamin C) of the mango after spray drying was higher than 65 .

\section{ACKNOWLEDGMENT}

The authors thank the University of Cartagena, Sucre and SENA for providing space, resources and time for researchers. The authors thank Álvaro Alberto Zabaleta Fuentes for their collaboration in the translation of the article into the English language.

\section{AUTHOR CONTRIBUTION}

All authors contributed equally

\section{CONFLICTS OF INTERESTS}

All authors have none to declare

\section{REFERENCES}

1. Castro A, Cardozo J, Isaza L, López A, Rodríguez S. Propuesta para el desarrollo de un clúster frutícola en el departamento de Cundinamarca. [Tesis de Pregrado]. Bogotá. Universidad del Rosario; 2011. Disponible en: http://repository.urosario. edu.co/bitstream/handle/10336/2279/1020734967-2011. pdf. [Last accessed on 10 Jun 2017].

2. Morillas-Ruiz JM, Delgado-Alarcon JM. Nutritional analysis of vegetable food with different origins: evaluation of antioxidant capacity and phenolic total compounds. Nutr Clin Diet Hosp 2012;32:8-20.

3. Kuskoski M, Asuero A, Troncoso A, Mancini-Filho J, Fett R. Aplicación de diversos métodos químicos para determinar actividad antioxidante en pulpa de frutos. Food Sci Technol 2005;25:726-32.

4. Zapata K, Cortes FB, Rojano BA. Polyphenols and Antioxidant Activity of Sour Guava Fruit (Psidium araca). Inf Tecnol 2013;24:103-12.

5. Penningtong J, Fisher R. Food component profiles for fruit and vegetable subgroups. J Food Comp Anal 2010;23:411-8.

6. Quintero V, Giraldo G, Lucas J, Vasco J. Physicochemical characterization of the common mango (Mangifera indica L.) during the ripening process. Biotecnol Sect Agropecu Agroind 2013;11:10-8

7. Ribeiro SMR, Schieber A. Bioactive compounds in mango (Mangífera indica L.) bioactive foods in promoting health: fruits and vegetables. Chapter 34. Elsevier Inc; 2010. p. 507-23.

8. Aguiar G, Favaro-Trindade C, Ferreira C. Microencapsulation of lycopene by spray drying: Characterization, stability and application of microcapsules. Food Bioprod Process 2012; 90:37-42.
9. Ahmed M, Akter MS, Lee JCh, Eun JB. Encapsulation by spray drying of bioactive components, physicochemical and morphological properties from purple sweet potato. LWT Food Sci Technol 2010;43:1307-12.

10. Esquivel-Gonzalez BE, Ochoa-Martinez LA, Rutiaga-Quinones OM. Microencapsulation of bio active compound $\mathrm{s}$ by spraydrying. Rev Iber Tecnología Postcosecha 2015;16:180-92.

11. Ersus S, Yurdagel U. Microencapsulation of anthocyanin pigments of black carrot (Daucus carota L.) by a spray drier. J Food Eng 2007;80:805-12.

12. Parra-Huertas RA. Revisión: microencapsulación de alimentos. Revista Facultad Nacional Agronomia. Medellín 2010;63:5669-84.

13. Lopez 0 . Microencapsulation of oily substances by aspersion drying. Rev Cubana Farm 2010;44:381-9.

14. Ramirez R, Arenas L, Acosta K, Yamarte M, Sandoval L. Effect of scalded on the nutritional quality pulp sour sop (Annona muricata L.). Rev Iber Tecnologia Postcosecha 2012;13:48-57.

15. Gil-Garzon M, Alzate-Tamayo L, Sanchez-Camargo A, MillanCardona L. Spray drying: an alternative to conserve bioactive and aromatic compounds from garlic extract (Allium sativum L.). Re Lasallista Investig 2011;8:40-52.

16. Soottitantawat A, Bigeard F, Yoshii H, Furuta T, Ohkawara M, Linko P. Influence of emulsion and powder size on the stability of encapsulated D-limonene by spray drying. Innov Food Sci Emerg Technol 2005;6:107-14.

17. Bule MV, Singhal RS, Kennedy JF. Microencapsulation of ubiquinone-10 in carbohydrate matrices for improved stability. Carbohydr Polym 2010;82:1290-96.

18. Pajaro-Castro NP, Leon-Mendez G, Osorio-Fortich MR, Torrenegra-Alarcon ME, Ropero J. Microencapsulation of Cinnamomum verum $\mathrm{L}$. essential oil by spray drying and its potential antioxidant activity. Rev Cubana Farm 2017. [Article in Prees].

19. Matiz GE, Leon G, Fuentes K. Microencapsulation of essential oil of thyme (Thymus vulgaris) in polymer matrices of modified yam starch (Dioscorearotundata). Rev Colomb Cienc Quim Farm 2015;44:189-207.

20. Granados-Conde C, Torrenegra-Alarcon ME. Antioxidant activity and phenolic content of Rheum rhabarbarum petiole. Rev Cubana Farm 2016;50:1.

21. Rojano BA, Vahos ICZ, Arbelaez AFA, Martinez AJM, Correa FBC, Carvajal LG. Polyphenols and antioxidant activity of the freezedried palm naidi (açai colombiano) (Euterpe oleracea Mart). Ver Fac Nal Agr Medellin 2011;64:6213-20.

22. Silva BM, Andrade PB, Valentão P, Ferreres F, Seabra RM, Ferreira MA. Quince (Cydonia oblonga Miller) fruit (Pulp, Peel, and Seed) and Jam: antioxidant activity. J Agric Food Chem 2004;52:4705-12.

23. Granados-Conde C, Torrenegra-Alarcón ME, Yanez-Rueda X. Evaluation of the antioxidant activity of essential oil of Myrcianthes leucoxyla obtained by two extraction methods. Rev Cubana Farm 2017;51:1.

24. Granados-Conde C, Torrenegra-Alarcón ME, Yañez-Rueda X. Extraction, characterization and antioxidant activity of essential oil from Eucalyptus globulus Labill. Rev Cubana Farm 2017;51:356-66.

25. Granados-Conde C, Torrenegra-Alarcon ME, Pajaro-Castro NP, Leon-Mendez G, Tejada C. Antioxidant activity of essential oil from Matricaria chamomilla L. Rev Cubana Farm. 2017;51:4-10.

26. Granados-Conde C, Yánez-Rueda X, Santafé-Patino GG. Evaluation of antioxidant activity of the essential oil of Calycolpus moritzianus y Minthostachys mollis of the North of santander (Colombia). Bistua 2012;10:12-23.

27. Re R, Pellegrini N, Proteggente A, Pannala A, Yang M, RiceEvans C. Antioxidant activity applying an improved ABTS radical cation decolorization assay. Free Radical Biol Med 1999;26:1231-7.

28. Leon G, Torrenegra M, Osorio MR, Gil J. Extraction, characterization and antioxidant activity of essential oil from Plectranthus amboinicus L. Rev Cubana Farm 2015;49:708-18.

29. Granados C, Santafe GG, Acevedo D. Chemical composition and evaluation of antioxidant activity of leaf essential oil Eucalyptus 
camaldulensis from norte de santander (colombia). Rev U. D. C. A Act Div Cient 2015;18:235-40.

30. Granados C, Yánez Y, Acevedo D. Evaluation of antioxidant activity of the essential oil of Myrcianthes leucoxyla from norte de santander (Colombia). Inf Tecnol 2014;25:11-6.

31. Patil V, Kumar ChA, Pratap SR. Optimization of the spray-drying process for developing guava powder using response surface methodology. Powder Technol 2014;253:230-6.

32. Caliskan G, Nur DS. The effects of the different drying conditions and the amounts of maltodextrin addition during spray drying of sumac extract. Food Bioprod Process 2013; 91:539-48.

33. Krishnaiah D, Sarbatly R, Nithyanandam R. Microencapsulation of Morinda citrifolia L. extract by spray-drying. Chem Eng Res Des 2012;90:622-32.

34. Mendoza FA, Arteaga M, Pérez O. Behavior of vitamin C in a product based on whey and variety Magdalena River mango (Mangífera Indica) during spray drying. Rev Chil Nutr 2016;43:159-66.
35. Ungar Y, Osundahunsi OF, Shimoni E. Thermal stability of genistein and daidzein and its effect on their antioxidant activity. J Agric Food Chem 2003;51:4394-9.

36. Moreiras O, Carbajal A, Cabrera L, Cuadrado C. Tablas de composición de alimentos. Ediciones Piramide. Madrid. España; 2006.

37. Pang SF, Yusoff MM, Gimbun J. Assessment of phenolic compounds stability and retention during spray drying of Orthosiphon stamineus extracts. Food Hydrocolloids 2014;37:159-65.

38. Tonon R, Brabet C, Hubinger M. Influence of process conditions on the physicochemical properties of acai (Euterpe oleraceae Mart.) powder produced by spray drying. J Food Eng 2008;88:411-8.

39. Goveas S, Abraham A. Evaluation of antimicrobial and antioxidant activity of stem and leaf extracts of Coscinium fenestratum. Asian J Pharm Clin Res 2013;6:218-21.

40. Jebitta R, Allwin J. Antioxidant activity, total phenol, flavonoid, and anthocyanin contents of Jamun (Syzygium cumini) pulp powder. Asian J Pharm Clin Res 2016;9:361-3. 